\title{
IS THE REGION OF VISEGRAD COUNTRIES ON THE TRACK TO THE EURO AREA? RECENT EVIDENCE FROM THE REAL CONVERGENCE PERSPECTIVE ${ }^{1}$
}

After enlargement of the European Union and subsequently joining of a new member states to the euro area, the question of economic convergence attracted considerable research interest. This paper adopts three alternative concepts to examine the level and trend of convergence in the Visegrad countries (Czech Republic, Hungary, Poland, Slovakia). We concurrently estimate the $\beta$-convergence, $\sigma$-convergence and business cycle synchronization to find out whether all countries are on the way towards higher convergence with the euro area. The results suggest that convergence of all countries has been increasing. However, the recent acceleration of the convergence process is caused mainly by external shocks in the form of the financial crisis and following economic slowdowns. Hence, the current level of convergence in the Visegrad countries cannot be considered as fully adequate.

Keywords: convergence, Visegrad countries, euro, area

\section{Introduction}

The concept of convergence is a complex issue from the economic theory perspective. Convergence is understood as an aligning development of economic variables while the difference between two or more variables at a time decreases. Therefore, it is seen as a process that is approaching a certain equilibrium level.

Originally, the mainstream of the convergence debate was the question whether income levels of poorer countries are converging to those of richer countries. Further, this question was linked to the economic growth theory. In particular, convergence was considered as an implication of the neo-classical growth theory. Therefore, testing for convergence was fre-

${ }^{1}$ (c) Stavárek D., Tomanová L. Text. 2014. quently used as a test of validity of alternative economic growth theories. Growing importance of convergence along with rising interest of investigators in this issue has consequently led to numerous different interpretations of convergence and a wide array of empirical results, so much that the current convergence research can give the impression of being spread across many aspects and disciplines.

The study [17] summarizes dichotomies that clearly indicate how differently the convergence can be understood in a literature. In addition, the following classification helps in orientation with what are the current trends in the dispute over convergence. ${ }^{2}$

\footnotetext{
${ }^{2}$ In addition, one can also speak about the convergence of consumer behavior, social stratification, legislation framework, and so on.
} 
1. Convergence within an economy vs. convergence across economies.

2. Convergence in terms of growth rate vs. convergence in terms of income level.

3 . $\beta$-convergence vs. $\sigma$-convergence.

4. Unconditional (absolute) convergence vs. conditional convergence.

5. Global convergence vs. local or club-convergence.

6. Income convergence vs. total factor productivity convergence.

7. Nominal convergence vs. real convergence.

8. Deterministic convergence vs. stochastic convergence. ${ }^{1}$

In this paper, we address convergence from the perspective of integration to the euro area. Accordingly, we restrict the analysis only on some of the above-mentioned classifications. We particularly deal with convergence across economies, however, on the local or club level. We compare results of alternative approaches including $\beta$-convergence and $\sigma$-convergence.

The real convergence usually captures approaching of standard of living (typically measured by GDP per capita in purchasing power parity basis) in different countries to a common longterm equilibrium state, thus how a less developed country catches up with more developed country. A comprehensive elaboration of this concept of the real convergence is provided in [12], [4] or [21]. Alternatively, the real convergence can be understood as synchronization of the business cycle of a country to the reference country or group of the countries [7] or as cohesion of individual regions/ countries within the integration group [8].

The phenomenon of economic convergence has been tightly connected with the process of economic integration. Convergence possesses a crucial importance in integration groups, particularly in economic and monetary unions. One can distinguish between two general approaches that link economic convergence and monetary integration. The first requires a sufficient level of business synchronization, which is considered as a precondition of joining the monetary union with a single currency and monetary policy. This concept is proposed by [18] or [6]. The second concept, by contrast, assumes that the convergence process is inherently stimulated and speeded up after a country joins the monetary union. As argued by [14], establishment of a monetary union strengthens trade ties and may lead to more closely synchronized business cycles.

\footnotetext{
${ }^{1}$ We refer to [18] or [35] for a detailed discussion on all convergence dichotomies.
}

After the eastern enlargement of the EU many of the EU newcomers already had joined the euro area and the remaining countries are likely to do so as well at some point. Therefore, economic convergence is one of the most important economic developments in the EU and the euro area, and there is a continuous need for evaluation of the progress achieved by the new member states in economic convergence. Although the EU evaluates new member states from a nominal convergence approach, and publishes the Convergence report annually, the real convergence seems to be a better tool for assessment of a country's preparedness to proceed with integration and join the monetary union. In other words, while the nominal convergence is a necessity for application and joining the euro area, the real convergence provides the assumption that benefits outweigh the cons of monetary integration.

The aim of the paper is to quantify and evaluate the convergence achieved by the group of Visegrad countries (Czech Republic, Hungary, Poland, Slovakia) towards the euro area. We use a parallel application of various empirical methods to obtain a relevant and full-bodied set of results. In particular, we estimate the $\beta$-convergence, $\sigma$-convergence and business cycle synchronization. The main advantage of this approach is that we can simultaneously examine outcomes of individual methods that shed some light on convergence from different perspectives. This is also the key aspect that distinguishes the present paper from previously published studies on convergence in the Visegrad countries (hereafter V4 countries), e. g. [19], [29] or [11]. In addition, the selection of the countries allows us to not only compare the level of convergence across the countries but also to reveal whether joining the euro area with a particular interest in Slovakia has stimulated the convergence process more than 'simple' membership in the EU.

The remainder of the paper is structured as follows. In Section 2, a review of relevant literature is provided. In Section 3, we examine the real convergence with the above-mentioned methods. Section 4 concludes the paper with a summary of main findings.

\section{Literature review}

The academic literature features a large number of studies that deal with convergence in the EU as well as in the euro area. Here, we report only the literature which is relevant to the present study in terms of methodology used, countries covered and empirical results obtained. We structure the literature review according to the concept of con- 
vergence examined in the cited papers. The same structure then applies for the empirical section of the paper to make our results easily comparable with outcomes of previous research.

A burgeoning set of literature has also been published in the field of real convergence of the EU new member states towards the euro area. However, the papers differ in many aspects such as country structure of datasets, period under estimation, and methods to determine the convergence or definition of a steady state. Hence, only a few robust patterns can be derived from these studies. First studies were applying the concepts of $\beta$-convergence and $\sigma$-convergence for analysis of real convergence in the Central and Eastern European (CEE) countries began to appear in the late 1990s. However, the studies employing sufficiently large datasets from CEE countries were published not earlier than 2002.

The studies usually came to the conclusion that real convergence in CEE countries had been relatively fast. For example [20] reports that seven CEE countries have converged significantly towards the average EU15 GDP per capita level in 1993-2001. Based on results of cross-sectional approach, he estimates the rate of income convergence of $3.4 \%$ annually for all CEE countries under estimation. He also finds an increase of $\sigma$-convergence if the seven CEE countries are included in the investigation group along with the old 15 EU members. These results are largely supported by findings in [30]. Using the pooled least squares method, they identify the rapidest process of convergence in Baltic countries followed by Hungary and Slovenia. The speed of converging with the EU level was especially remarkable during the period 2001-2004 when the growth differential between EU15 and the accession countries was around $2.2 \%$ per annum. They also discovered a reduction in the dispersion of income levels between the accession countries, which is evidence that $\sigma$-convergence also existed. Similarly with previously cited studies, [23] use data on GDP per capita at purchasing power parity standards and other economic indicators like industrial production or business confidence and apply them on pooled regression analysis to estimate the speed of $\beta$-convergence. They show that the rate of real convergence was higher in the period 1998-2003 (4.1\%) than in the period 1993-1998 (2.7\%). Next, [28] estimated $\beta$-convergence for some Central European countries (Czech Republic, Slovakia, Slovenia, Poland, and Hungary) from 1992 to 2004. The results support convergence to the EU15 countries by $1.74 \%$ annually and new EU member countries converge to the EU average by $1.77 \%$ annually.
The recent literature which covers the period after the EU enlargement in 2004 confirms the previous findings on ongoing real convergence in CEE countries towards the EU. For instance, [31] present analysis of $\beta$-convergence and $\sigma$-convergence among 10 new EU members and extend the estimation period to the end of 2006. Estimations of panel regressions lead to the conclusion that the speed of convergence accelerated over time. During 1995-2006 and 2002-2006, convergence occurred at the rate of $7.0 \%$ and $9.6 \%$, respectively. This implies effective integration going on among the 10 new member states which joined EU in 2004. They also confirm presence of $\sigma$-convergence and its hastening in 2003-2006. Contemporary studies also come up with new approaches to estimation of the real convergence pace. Further, [1] introduced Gini coefficients estimated on basis of Lorenz curve model as a tool for measurement of real convergence in CEE countries. One such estimating procedure in case of the GDP per capita time series in the period 20002011 demonstrated an accentuated convergence process inside the group of 10 new members, but a significant divergence inside the group EU15. The crisis seems to have no detectable impact on the convergence process inside of the two groups of EU countries. The study [24] uses Bayesian model averaging (BMA), time dummies and Blundell and Bond's GMM system estimator on new EU members data from 1993-2010.The analysis revealed that the EU27 countries converged at the rate of about $5 \%$ per annum during the EU15 countries at $3 \%$ per annum.

The synchronization of business cycles among EU member states, both within the euro area and between candidate countries and the monetary union, has been studied extensively in the literature. There are two basic questions raised in the business cycles synchronization literature. First, the authors attempt to find out whether a common business cycle exists within a group of countries. Second, the level of business cycles synchronization of a particular country is estimated in order to determine whether this country could be a member of the monetary union. A lack of synchronization would mean inefficient use of the single currency and thus an obstacle for entering the euro area.

The paper [2] analyzed common growth of business cycles in European countries over the period 1970-1996 on the data of Industrial Production and GDP using the Markov-Switching Autoregressive Model and came to the conclusion of suggesting an existence of a common European cycle. Using the VAR model, their analysis also 
confirmed existence of an ongoing convergence process. By contrast, [9] applied similar analysis to a set of EU countries, new EU member states and some industrialized countries. They argue that strong synchronization was found only in the core EU countries, but they found no evidence in favor of the existence of just one European business cycle. Next, [15] applied meta-analysis and surveyed nearly 30 studies with almost 350 point estimates of business cycle correlation between central and eastern European countries and the euro area. The results show that economic cycles in these countries are highly correlated with the euro area cycle, especially in the case of Hungary, Poland and Slovenia. For the majority of the new EU members, the business cycle correlation is sufficiently high as not to hinder a membership in the monetary union.

The most recent literature confirms previous results and provides evidence on the continuing process of convergence. The study [25] analyzed business cycles synchronization of central and eastern European and Baltic countries using a rolling window correlation of GDP and industrial production time series. The results suggest changing convergence patterns and point to diverging trends in CEE countries between 2001 and 2007. However, countries converged significantly during 2008-2011 which possibly reflects negative GDP performance of developed European economies. Moreover, [18] support this conclusion by their finding of a global European factor ${ }^{1}$ that captures well the sharp fall in real output observed during 2008 and 2009, and the weak recovery in 2010 and 2011. Their results also show that the business cycle of most euro area countries is extremely tightly matched with the global European factor. Most central and eastern European countries (with the exception of the Czech Republic) also show a strong correlation with the European business cycle.

\section{Real convergence in the visegrad countries}

The real convergence is based on the neoclassical growth theory, which deals with the convergence of economic variables to a steady state and is understood as convergence of economic level of one country to other country's economic level [32]. Real convergence is usually expressed in terms of GDP per capita. International comparisons are performed in terms of purchasing power parity (PPP), which reflects the purchasing power of the

\footnotetext{
${ }^{1}$ Global European factor is one the factors included in the multi-factor model thought to characterize the temporal comovements in the cross-country panel of time series.
}

domestic currency and thus eliminates price differences between economies. The relationship between two economies' levels can be formally written as follows:

$$
\frac{y_{1, t-1}}{y_{2, t-1}}<\frac{y_{1, t}}{y_{2, t}} \text { for } y_{1, t}<y_{2, t}
$$

where $y$ is the real income of country 1 and 2 at the time $t-1$ and $t$. This relationship can be interpreted as decreasing of the relative distance of economic levels over time.

Real convergence can also be understood as a structural convergence of economies or used technologies [28]. In this paper, we estimate the convergence of GDP per capita that is the most commonly used indicator when estimating the economic convergence. We particularly analyze real convergence by considering the process of approximation of the V4 economies to the average levels of income of the euro zone countries as more advanced countries. The process of convergence can be formulated similarly based on the absolute difference, written as follows [28]:

$$
\left|y_{1, t-1}-y_{2, t-1}\right|>\left|y_{1, t}-y_{2, t}\right|
$$

where $y_{1, t}$ and $y_{2, t}$ again represent the GDP per capita of two different countries (V4 country and the euro area) in current $(t)$ and previous $(t-1)$ time periods. When the opposite sign occurs, the situation is called divergence, meaning the economic levels of two countries are drifting apart from each other.

\section{1. $\beta$-convergence}

The $\beta$-convergence refers to a process in which poor countries grow faster than richer countries; therefore, the growth rate of poorer economies' income should catch up with richer economies. This concept is closely related to neo-classical growth theory, in terms of diminishing returns to capital as an explanation why poor countries (with a lower amount of capital) tend to grow faster. The growth should lead economies to a longrun steady state. The neo-classical theory distinguishes two types of convergence, unconditional and conditional convergence. Unconditional (absolute) convergence implies the convergence of the economy to its steady state, which stands for the situation when output per capita is constant in time [26]. In this case, other structural factors are omitted in the model since it is assumed that the economies do not differ significantly in the institutional framework, foreign trade development, population literacy, the investment ratio, and level of technology. For conditional convergence estimation, it would be necessary to include the set of such structural variables. 
$\beta$-convergence is typically tested by regressing the growth measured as GDP per capita on the initial relative level across a cross-section of countries. Following the concept proposed by [3], $\beta$-convergence can be approximated by:

$$
\frac{1}{T} \log \left(\frac{y_{i, T}}{y_{i, 0}}\right)=\alpha+\beta \log \left(y_{i, 0}\right)+\gamma Z_{i, T}+\varepsilon_{i},
$$

where the left side of equation expresses average growth rate of real GDP per capita in period 0 to $T$ depending on its initial level $y_{i, 0}, T$ is the number of years from 0 to $T, Z$ includes other factors supposedly affecting the growth rate (if other factors are not included, the convergence is said to be unconditional). Coefficients $\beta, \gamma$ and $\alpha$ are parameters to be estimated and $\varepsilon_{i}$ is a residual component. If a negative relationship between the growth rate and the initial level of GDP per capita $y_{i, 0}$ is significant and negative, the sign of ongoing convergence process can be confirmed. The estimated value of $\beta$ also reflects the rate of convergence towards the steady state.

Equation (3) implies the convergence of measuring the size difference in steady state, longterm level with constant income per capita (at zero growth). However, we do not assume zero growths but consider GDP development through the analyzed period. Therefore, we determined a steady state as the economic performance of the euro area (EA 17) countries. Our model is based on nonlinear regression and estimated by the classical method of least squares. We estimate a separate model for each country rather than estimating groups of countries following a model specification proposed in [16]. A similar approach was used e.g. in [10]:

$$
\log \left(\frac{y_{i, t}}{y_{E A, t}}\right)=\alpha_{i, t}+\beta_{i, t} \log y_{E A, t}+\varepsilon_{i, t},
$$

where $\frac{y_{i, t}}{y_{E A, t}}$ is the GDP per capita in purchasing power parity standards of a Visegrad country $i$ divided by average level of real euro area GDP per capita in time $t, \alpha_{i, t}$ is a constant, $\beta_{i, t}$ represents a regression coefficient, $\varepsilon_{i, t}$ represents a random component and $t$ denotes the years from 1995 to 2012. An important target of the empirical research is to estimate the value of parameter $\beta_{i, t}$ since convergence occurs in the case of a positive slope of $\beta_{i, t}$. A positive slope is caused by the economies' convergence from the bottom towards the euro area level. On the other hand, a negative sign of the parameter value indicates $\beta$-divergence.

The analysis covers the period 1995-2012 and is based on annual GDP per capita at purchasing power parity standards. All data used are drawn from the Eurostat database. Based on the estimation of separate national models we obtained four regression parameters of $\beta$-convergence. All important estimation results are summarized in Table I. During estimation, we applied all standard diagnostic tests and, hence, the models are verified to be statistically and econometrically correct. We are particularly interested in value and significance of parameter $\beta$ because these are indicators whether the process of convergence is ongoing.

The estimated regression coefficients are statistically significant at the $1 \%$ significance level. This means that we can objectively evaluate, on the basis of the formulation of the model (4) that the real convergence in all V4 countries occurred during the period of estimation. However, the speed of convergence differed across the countries. Relevance of the obtained results is also evidenced by the relatively high value of the coefficient of determination $\left(R^{2}\right)$.

We found the strongest evidence of convergence to the euro area in Slovakia where the coefficient $\beta$ reached value of 1.12 . If the period of estimation is widened to 1994-2012, we can observe an even faster pace of convergence of 1.77. Slovakia is followed by Poland and Hungary with coefficient $\beta$ of 0.87 and 0.74 respectively. We identified the Czech Republic as the Visegrad country with the slowest real convergence towards the EA 17 average. The respective coefficient $\beta$ was only 0.36 which is roughly three times less that in Slovakia and half of the two other analyzed countries. Results on convergence for the V4 countries are generally in line with the results obtained by other researchers as far as the general finding of ongoing real convergence is concerned. The results indicate that economic growth paths of the V4 countries confirm the existence of $\beta$-convergence. However, the speed of convergence estimated in the present study seems to be slower than suggested by previous research. Only results for Slovakia, which is the only euro area member country in our sample, confirm values of the coefficient $\beta$ (speed of convergence) that have been estimated in earlier studies.

\section{2. $\sigma$-convergence}

The previous results confirmed the existence of conditional $\beta$-convergence of Czech Republic, Hungary, Poland and Slovakia to the euro area. While $\beta$-convergence focuses on possible process of catching-up, $\sigma$-convergence refers to a reduction in the dispersion of levels of income across economies. The advantage of this approach is in its simplicity as it directly describes the distribution of income without relying on particular 
Estimations of $\beta$-convergence

\begin{tabular}{|c|c|c|c|c|c|}
\hline & & coefficient & std. error & t-stat & p-value \\
\hline \multirow[t]{3}{*}{ Czech Republic } & $a$ & -1.7459 & 0.3126 & -5.5852 & 0.0000 \\
\hline & $\beta$ & 0.3631 & 0.0716 & 5.0697 & 0.0001 \\
\hline & $R^{2}$ & 0.6163 & & & \\
\hline \multirow[t]{3}{*}{ Hungary } & $a$ & -3.4789 & 0.2681 & -12.9786 & 0.0000 \\
\hline & $\beta$ & 0.7339 & 0.0614 & 11.9519 & 0.0000 \\
\hline & $R^{2}$ & 0.8993 & & & \\
\hline \multirow[t]{3}{*}{ Poland } & $a$ & -4.1427 & 0.5141 & -8.0576 & 0.0000 \\
\hline & $\beta$ & 0.8727 & 0.1178 & 7.4084 & 0.0000 \\
\hline & $R^{2}$ & 0.7743 & & & \\
\hline \multirow[t]{3}{*}{ Slovakia } & $a$ & -5.1622 & 0.5538 & -9.3219 & 0.0000 \\
\hline & $\beta$ & 1.1193 & 0.1269 & 8.8221 & 0.0000 \\
\hline & $R^{2}$ & 0.8295 & & & \\
\hline
\end{tabular}

Source: Authors' calculations based on data from Eurostat

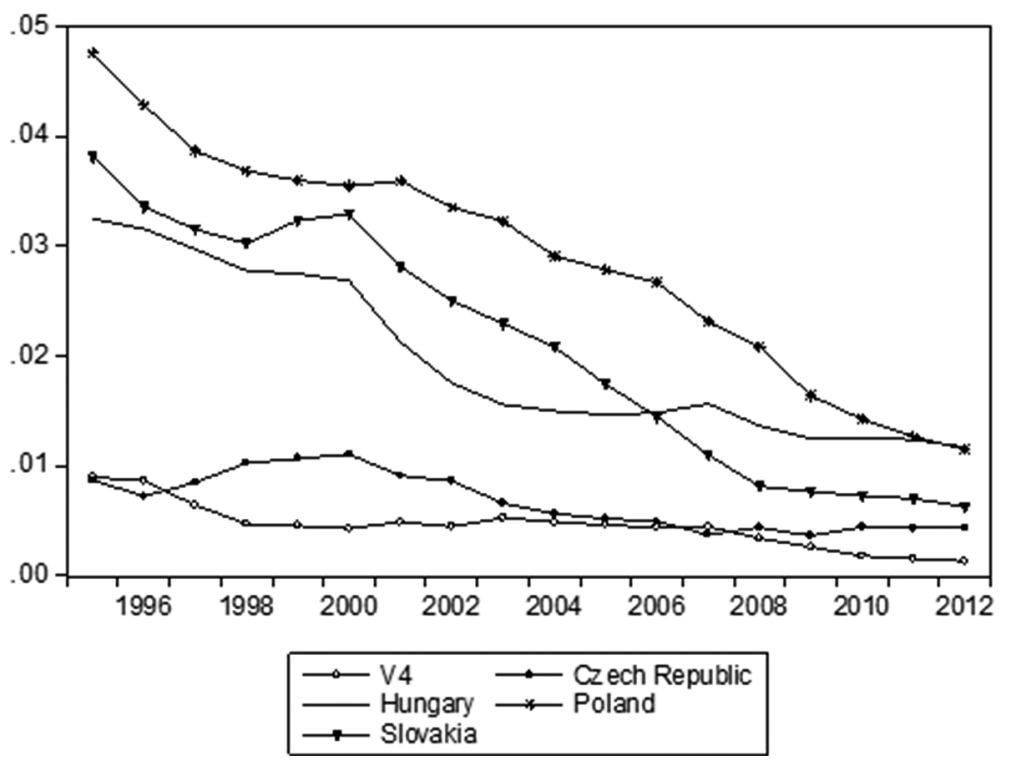

Fig. 1. Log of GDP per capita variance development. Source: Authors' calculations based on data from Eurostat

model estimation. Criterion of $\sigma$-convergence was constructed in order to obtain additional information on the convergence path. Similarly with the $\beta$-convergence, it is also based on the neoclassical growth model according to which all countries converge to the same level of maturity or to the same economic performance. In general, less advanced countries grow faster than more advanced countries; however, this does not guarantee a systematical reduction of income dispersion between these countries. Existence of $\beta$-convergence is a necessary condition for $\sigma$-convergence; however, the reverse relationship may not apply [5]. The $\sigma$-convergence takes place if the less developed areas close the gap in per capita income between them and a more affluent economies over time. Thus, $\sigma$-convergence is defined as a reduction of variance of real GDP per capita logarithm between economies over time. The coefficient of variation is a normalized measure of dispersion of a probability distribution. It is defined as the ratio of the standard deviation to the mean. If we denote the variance of the logarithm of real GDP per capita in the group of countries at time $t$, then the $\sigma$-convergence between period $t$ and $t+1$ can be expressed as:

$$
\sigma_{t}>\sigma_{t+1}
$$

To test $\sigma$-convergence, we analyze the tendency of income dispersion by estimating the variance of GDP per capita in purchasing power parity standards. The estimation was made for the period 1995-2012. Verification of $\sigma$-convergence can be best accomplished through visible changes of variance from a chart. For this reason, we present Figure 1 that depicts development of variability 
coefficients in income between V4 countries and separately between a particular country and EA 17 average.

It is shown that even if income dispersion among the V4 countries was generally decreasing, one can also observe some episodes of increased dispersion. While the disparities among V4 countries remained relatively stable during the period 1998-2007, the recent development shows greater convergence even within the V4 region. In the case of particular countries, the convergence process towards the EA 17 accelerated in 2000 (post-transformation period) and has been continuing since then. Hungarian variance, on the other hand, increased in 2007, caused by economic slowdown connected with the reduction of domestic demand and expenditures as a result of fiscal measures. Moreover, after the outbreak of the crisis in the USA, Hungary was the first V4 country which was fully hit by its global implications.

In the next period, the convergence process continued until 2009. A slight slowdown of convergence occurred since 2009 in the case of Slovakia and Poland, which reflects the economic downturn. In the case of the Czech Republic, income differentiation increased in the period 19962000 when the Czech Republic faced an economic downturn caused by a combination of issues (lingering transformation, structural changes, and currency crisis). Development of variance gained a slight increasing trend again during 2010-2012. It is evident that the dispersion between particular Visegrad countries and the euro area has significantly decreased over the analyzed period. Hence, the $\sigma$-convergence approach reveals ongoing convergence of the V4 countries towards the euro area. In summary, we can conclude that the absolute convergence of the V4 countries towards the euro area revealed in the $\beta$-convergence estimations is confirmed by results of the $\sigma$-convergence.

\subsection{Synchronization of business cycles}

Joining the euro area is automatically associated with implementation of a common monetary policy that reflects economic development of the entire monetary union and not a single country. Therefore, the common monetary policy can cause disadvantages in terms of higher economic costs for a country that is in a different stage of the economic cycle than the euro area average. In terms of the theory of optimum currency areas, participation in the euro area of a country with higher synchronization of the business cycle is less costly than for a country with low synchronization. The occurrence of asymmetric shocks in a monetary union may hamper monetary policy implementation. If a potential member of a monetary union is sub- ject to symmetric economic shocks, the benefits of a common currency exceed the cost of relinquishing a national autonomous monetary policy [6]. The business cycle synchronization is, therefore, a complement to the real convergence analysis since it takes a different view on joining the monetary union. By estimation of business cycle synchronization, we can reveal whether a sufficient level of achieved convergence would not be ruined by a divergence in business cycle evolution. Therefore, we consider the analysis of the business cycle synchronization as essential to complete the investigation of the V4 convergence to the euro area.

Cyclical synchronization can be estimated by means of correlation coefficients. Therefore, if business cycles correlation between V4 countries and the euro area is sufficiently high and significant, these countries fulfil the condition of a cyclical synchronization, which suggests better preparedness for single currency adoption and the subsequent benefits. A simple method to determine the cyclical synchronization is to compute correlation coefficients between V4 and euro area cycles. If there is a significant correlation between the cycles, the analyzed economies should respond similarly to external shocks. If the correlation is not significant, it would not be possible to set up a common economic policy so that the policy would result in desirable economic development.

To obtain a more comprehensive picture, correlation of economic activity in the industry is also applied. We use the indicators of GDP and Industrial Production (IP) to approximate business cycles. We included data on industrial production because they are available at higher frequency than GDP data. This paper uses quarterly, seasonally adjusted real GDP data series for the period 1995-2012 and the period 2000-2012 in the case of industrial production index. We use a rolling correlation approach with a five-year window in both cases, which appropriately describes the dynamics of business cycle relations between the V4 countries and the EA 17 and refers to correlation of a previous five year sample. We have applied the Hodrick-Prescott filter on logarithms of seasonally adjusted GDP in current prices and IP $(2010=100)$ and run the rolling correlation with cyclical components of the time series. The synchronization can be recognized by observing the evolution of a correlation. The correlation coefficients between the euro area cycle and V4 countries' cycles are portrayed in Figures 2 and 3. If the correlation of a country reaches positive and significant values, the convergence can be confirmed. A higher correlation coefficient obviously indicates a higher degree of convergence. 


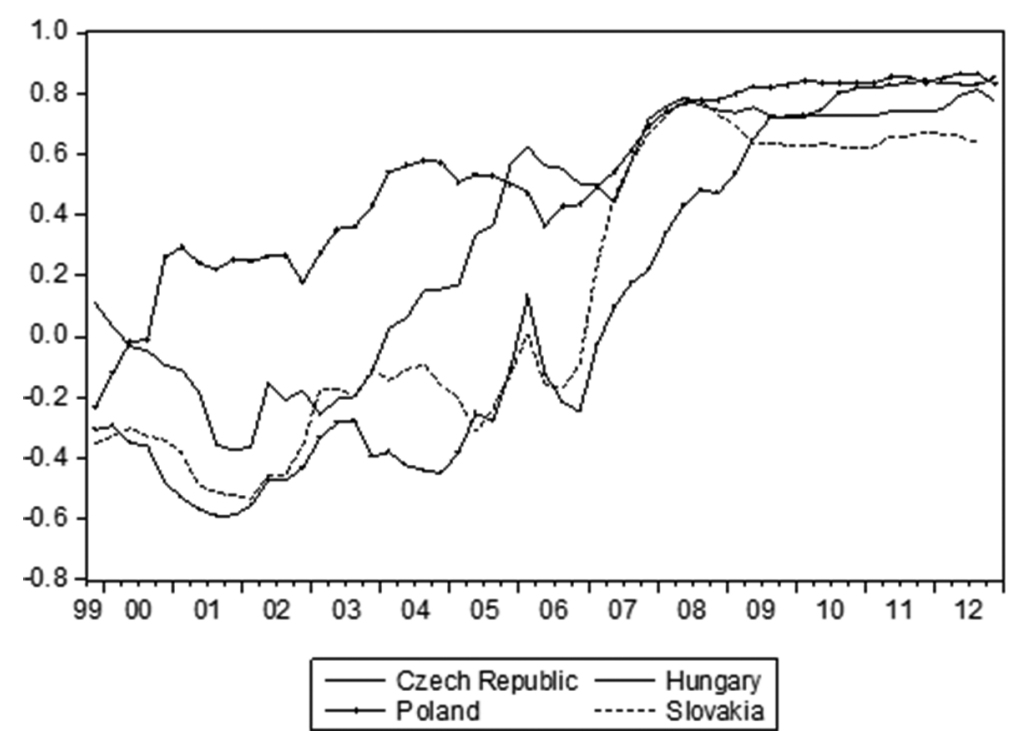

Fig. 2. Five-year rolling correlation of business cycles (GDP) to the EA17 average. Source: Authors' calculations based on data from Eurostat

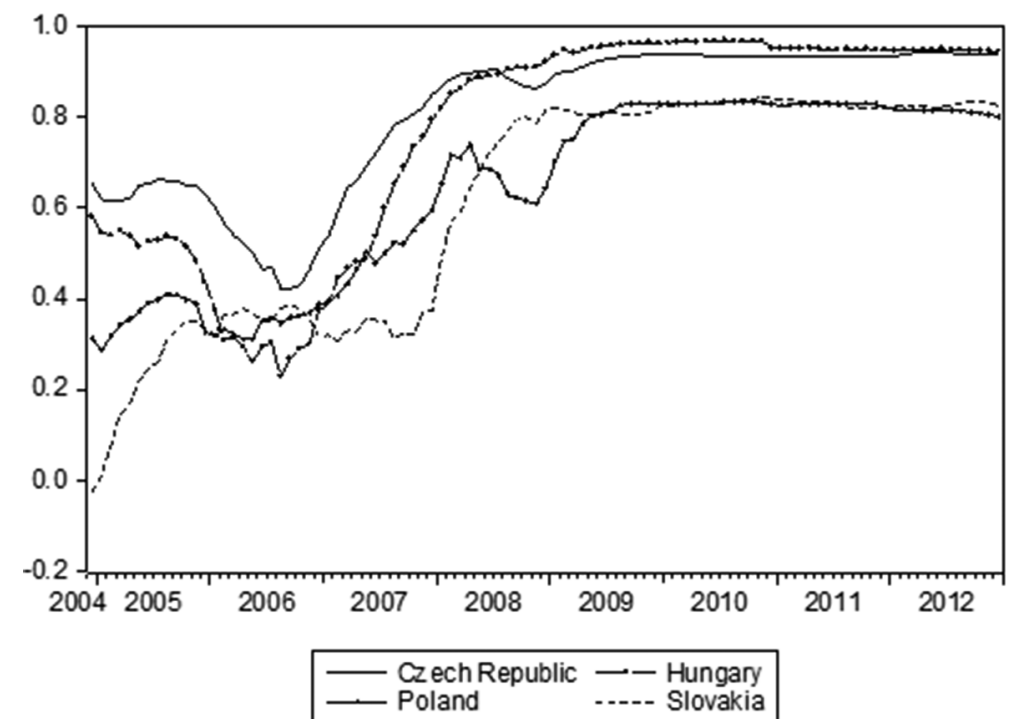

Fig. 3. Five-year rolling correlation of business cycles (IP) to the EA 17 average. Source: Authors' calculations based on data from Eurostat

Figure 3 shows the five-year rolling correlation of business cycles derived from GDP. A converging trend is significant, especially in recent years (2008-2012). However, estimation also reveals a divergence of business cycles before the hit of the financial crisis. A sharp increase of correlation since 2008 in the case of all V4 countries can be partly attributed to an increase in business cycle synchronization; however, the effect of a severe economic downturn probably had a dominant impact. During 2007, the pace of economic growth began to slow in V4 countries and the euro area, which can be interpreted as a transition to a downward phase after reaching the peak of the economic cycle. Among the V4 countries, Poland shows strong improvement in cyclical correlation since 2002 and a great synchronization of the business cycle with the euro area business cycle since the end of 2007. A converging trend started to take place in the case of the Czech Republic in 2005 with coefficients ranging from $0.3-0.6$ which is rather sharp increase. The Hungarian cycle shows almost no tendency to move toward greater synchronization and thus reveals a diverging trend until 2007. Regarding Hungary's GDP and economic situation development, domestic factors had a significant influence on the cycle. Surprisingly, Slovakia shows a similar pace of the correlation coefficients as Hungary. Although increasing synchronization since 2007 can indicate a higher convergence of all V4 countries, one should bear in mind that this was mainly caused by an external shock and its effect is likely to vanish over time. Hence, the conclusion that business cycles synchronization is high, convergence sufficient and monetary integration easily practicable 
would be misleading. In other words, the recent high correlation coefficients should not be used as an argument in favor of joining the euro area in the near future.

Figure 3 shows the correlation of industrial production indices of V4 countries to the euro area in the period from 2004 to 2012. All V4 countries show a great convergence during 2009-2012. The recent levels of convergence are at a stable and high level close to the range $0.8-1$. Figure 3 indicates a strong influence of recession and subsequent slow recovery of the economies in the last period. The correlation of the Czech Republic and euro area countries average industrial production was significant throughout the whole period with a downward trend in 2005 - mid-2006. Since then the correlation rose significantly and after a slight decline in 2008, the correlation increased since 2009 and remains at high levels. In 2008, the Czech Republic was caught-up in terms of business cycles convergence by Hungary. Slovakia and Poland maintain similar levels of correlation since 2009; however, Slovakia has shown an increasing trend of correlation since 2007, meanwhile, Poland faced a downturn in correlation in 2008. These results are consistent with [25], [15] and [18]. ${ }^{1}$

\section{Conclusion}

The aim of this paper was to quantify and evaluate the level of convergence achieved by the group of V4 countries towards the euro area. A low rate of convergence can indicate some challenges in terms of euro adoption, which is confirmed by developments in the euro area countries over the last few years. We adopted a multi-dimensional approach and concurrently examined nominal and real convergence by alternative methods.

We employed three methods to estimate real convergence of the V4 countries. The outputs of

\footnotetext{
${ }^{1}$ On the other hand [9] argue that strong business cycle synchronization was found only in the core EU countries.
}

all estimation unanimously suggest that the convergence is an ongoing and continuous process, and the level of real convergence in all countries has been increasing. The respective coefficients in the $\beta$-convergence estimations are significant in all countries. Based on the $\sigma$-convergence concept, dispersion of income levels has been reduced over time, although slightly slowing since 2009. Estimations of business cycles synchronization provide mixed results. Whereas the pre-crisis period is characteristic of a diverging trend in many countries, the recent financial crisis and following economic recession established a new trend of rising synchronization.

In summary, we revealed robust evidence of continuing convergence in the V4 countries. We also found that the convergence is more perceptible the in case of Slovakia in terms of $\beta$-convergence and $\sigma$-convergence, according to IP cycles synchronization converging faster since joining the EU. However, according to GDP cycles synchronization approach, Slovakia is a country with the least synchronized cycle until 2007. On the other hand, business cycles are now more synchronized due to external shock in the form of a financial crisis not due to fundamental approximation of the economies. Subsequently, joining the euro area may still cause serious economic problems in the V4 countries with independent monetary policy. Based on the results obtained, and convergence trends revealed we could suggest a clear policy implication for the three non-euro V4 countries. Although the level of convergence seems to be sufficient, staying outside the euro area and keeping independent monetary policy is desirable. At least until the next growth stage of the economic cycle is over. This time is necessary to prove if the increased convergence obtained in the post-crisis period is not only temporary and spurious episode, but it can also persist in a more standard economic environment.

Research behind this paper was supported by the Student Grant Competition of Silesian University within the project SGS/7/2013 "Effect of exchange rates on companies and economic environment in small open economies." The support is gratefully acknowledged. We also thank Adrienne Dinneen for comments and suggestions on an earlier version of the paper.

\section{References}

1. Albu, L. L. (2012). The convergence process in the EU estimated by Gini coefficients, Romanian Journal of Economic Forecasting 4, 5-16.

2. Artis, M. J., Krolzig, H., \& Toro, J. (2002). The European Business Cycle, Economic Working Papers at Centro de Estudios Andaluces, E2002/19.

3. Barro, R. J. \& Sala-i-Martin, X. (1991). Convergence Across States and Regions, Brookings Papers on Economic Activity, 22,107182.

4. Barro, R. J., \& Sala-i-Martin, X. (2004). Economic growth, 2nd ed. Boston: MIT Press.

5. Barro, R. J. \& Sala-i-Martin, X. (1992). Public Finance in Models of Economic Growth, The Review of Economic Studies, 59, 645-661. 
6. Bayoumi, T. \& Eichengreen, B. (1997). Ever closer to heaven? An Optimum-Currency-Area Index for European Countries, European Economic Review, 41 , 761-770.

7. Begg, I. (2005). Catch-up, the Transition to Full Participation in EMU and Financial Stability, Paper presented at Research Conference on Financial Stability and the Convergence Process in Europe, Brussels . Available at: http://ec.europa.eu/economy_finance/events/2005/bxlforum1005/begg_en.pdf.

8. Bradley, J., Morgenroth, E. \& Untiedt, G. (2003). Macro-regional Evaluation of the Structural Funds Using the HERMIN Modelling Framework. Economic and Social Research Institute (ESRI). Working Paper no. 152. Available at: http://www-sre.wuwien.ac.at/ersa/ersaconfs/ersa03/cdrom/papers/313.pdf.

9. Camacho, M., Perez-Quiros, G. \& Saiz, L. (2005). Do European Business Cycles Look Like One? Banco de Espaňa Working Papers, 0518.

10. Canova, F., \& Marcet, A. (1995). The Poor Stay Poor: Non-Convergence Across Countries and Regions, CEPR Discussion Papers, 1265.

11. Drastichová, M. (2012). The relations of real and nominal convergence in the EU with impacts on the euro area participation, Central European Review of Economic Issues, 15 , 107-122.

12. de la Fuente (2000). Convergence Across Countries And Regions: Theory And Empirics, CEPR Discussion Papers, 2465.

13. Frait, J., \& Komárek, L. (2004). Exchange Rate and Monetary Developments in Accession Countries, in: S. Polouček, (ed.), Reforming the Financial Sector in Central European Countries, Houndmills, Basingstoke: Palgrave Macmillan, $169-210$.

14. Frankel, J. A. \& Rose, A.K. (1998). The Endogeneity of the Optimum Currency Area Criteria, Economic Journal, 108, 10091025.

15. Fidrmuc, J., \& Korhonen, I. (2006). Meta-analysis of business cycle correlation between the euro area and CEEC's, J Comp Econ, 34, 518-537.

16. Hančlová, J., Kubicová, I., Melecký, A., Melecký, L., Melecký, M., Ramík, J., Nevima J. \& Macháček, M. (2010). Makroekonometrické modelování české ekonomiky a vybraných ekonomik EU, Ostrava: VŠB-TU Ostrava, 190-280.

17. Islam, N. (2003). What have we learnt from the convergence debate? Journal of Comparative Economics, 17, 309-362.

18. Jiménez-Rodríguez, R., Morales-Zumaquero, A. \& Égert, B. (2013). Business Cycle Synchronization between Euro Area and Central and Eastern European Countries, Review of Development Economics, 17, 379-395.

19. Kowalski, P.A. (2003). Nominal and real convergence in alternative exchange rate regimes in transition countries: Implications for the EMU accession. CASE Network Studies and Analysis, 270, Warsaw: Center for Social and Economic Research.

20. Kaitila, V. (2004). Convergence of Real GDP per capita in the EU15. How do the accession countries fit in? ENEPRI Discussion Paper, 25.

21. López-Salido, J.D. \& Quirós, G.P. (2006). Real Convergence, Cyclical Synchrony and Inflation Differentials . The Analysis of the Spanish Economy: Data. Instruments and Procedures, Banco de Espaňa, 409-433. Available at: http://www.bde.es/f/webbde/SES/ Secciones/Publicaciones/OtrasPublicaciones/Fich/analysis_spanish_economy.pdf

22. Masson, P.R. \& Taylor, M.P. (1992). Common Currency Areas and Currency Unions: An Analysis of the Issues, CEPR Discussion Papers, 617

23. Matkowski, Z. \& Próchniak, M. (2004). Real Economic Convergence in the EU Accession Countries. International Journal of Applied Econometrics and Quantitative Studies, 3 , 5-38.

24. Próchniak, M. \& Witkowski, B. (2013). Time stability of the beta convergence among EU countries: Bayesian model averaging perspective, Economic Model, 30, 322-333.

25. Rozmahel, P. (2011). Real Convergence Trends in CEE Countries: Time varying correlation approach, Acta Academica Karviniensia, 2, 156-164.

26. Sala-i-Martin, X. (1994). Cross-sectional Regressions and the Empirics of Economic Growth. European Economic Review, 38, $739-747$.

27. Schadler, S., Drummond, P. Kuijs, L., Murgasova Z. \& R. van Elkan (2005). Adopting the Euro in Central Europe. Challenges of the Next Step in European Integration, IMF Occasional Paper, 234 , Washington, DC: International Monetary Fund.

28. Slavík, C. (2007). Real convergence of the Czech Republic to the EU in comparison with the other new member countries, Politická ekonomie, 54, 23-40.

29. Spěváček, V. \& Vintrová, R. (2010). Růst, stabilita a konvergence české ekonomiky letech 2001-2008, Politická ekonomie, $58,20-47$

30. Varblane, U. \& Vahter, P. (2005). An Analysis of the Economic Convergence Process in the Transition Countries, University of Tartu - Faculty of Economics and Business Administration, Working Paper Series, 37.

31. Vojinović, B., Acharya, S. \& Próchniak, M. (2009). Convergence analysis among the ten European transition economies, Hitotsubashi Journal of Economics, 50, 123-141.

32. Ždárek, V. \& Šindel, J. (2007). Real and Nominal Convergence and the New EU Member States -Actual State and Implication, Prague Economic Paper, 3, 197-215.

\section{Information about the authors}

Stavárek Daniel (Karvina, Czech Republic) - PhD, Professor, Department of Finance, School of Business Administration in Karviná, Silesian University in Opava (Univerzitní nám. 1934/3, 73340 Karviná, Czech Republic, e-mail: stavarek@opf.slu.cz).

Tomanova Lucie (Karvina, Czech Republic) - PhD candidate, Department of Finance, School of Business Administration in Karviná, Silesian University in Opava (Univerzitní nám. 1934/3, 73340 Karviná, Czech Republic, e-mail: tomanova@opf.slu.cz). 